\title{
REVIEW
}

\section{Whiplash associated disorders: a review of the literature to guide patient information and advice}

\author{
T McClune, A K Burton, G Waddell
}

Emerg Med J 2002;19:499-506

See end of article for authors' affiliations

....................

Correspondence to: Tim McClune, 30 Queen Street, Huddersfield HDI 2SP, UK;

tim@spineresearch.org.uk

Accepted for publication 14 June 2002

\begin{abstract}
Objectives: To review the literature and provide an evidence based framework for patient centred information and advice on whiplash associated disorders.

Methods: A systematic literature search was conducted, which included both clinical and non-clinical articles to encompass the wide range of patients' informational needs. From the studies and previous reviews retrieved, 163 were selected for detailed review. The review process considered the quantity, consistency, and relevance of all selected articles. These were categorised under a grading system to reflect the quality of the evidence, and then linked to derived evidence statements.

Results: The main messages that emerged were: physical serious injury is rare; reassurance about good prognosis is important; over-medicalisation is detrimental; recovery is improved by early return to normal pre-accident activities, self exercise, and manual therapy; positive attitudes and beliefs are helpful in regaining activity levels; collars, rest, and negative attitudes and beliefs delay recovery and contribute to chronicity. These findings were synthesised into patient centred messages with the potential to reduce the risk of chronicity.

Conclusions: The scientific evidence on whiplash associated disorders is of variable quality, but sufficiently robust and consistent for the purpose of guiding patient information and advice. While the delivery of appropriate messages can be both oral and written, consistency is imperative, so an innovative patient educational booklet, The Whiplash Book, has been developed and published.
\end{abstract}

W hiplash injuries and in particular the development of chronic pain and disability, are an increasing clinical and social problem. During treatment, clinicians typically provide patients with some information and advice but its form, content, and possible value vary considerably.

The concept of evidence based health care has fostered an increasing interest in patient information. The quantity of patient information material, covering most medical conditions, is now vast and available in multi-media format including pamphlets, books, videos, and internet sites. However, this material is of widely varying quality, ${ }^{1}$ much of it simply representing the views of individuals or interest groups without any firm evidence base. The Toronto Statement on the Relationship Between Communication and Practice and Outcomes ${ }^{2}$ recognised that: communication problems in medicine are both important and common; suitable explanations can diminish anxiety and psychological distress; the quality of information is related to positive health outcomes. There is emerging evidence that appropriate written material can be an effective component in the management of musculoskeletal conditions, ${ }^{3}$ while poor information, or misinformation, can adversely affect health behaviour and health outcomes. $^{4}$

The Quebec Task Force (QTF) on whiplash associated disorders (WAD), suggested that information is an essential part of an active management approach. It recommended that information should focus on the self limiting nature of WAD, and include advice to return to normal activities as soon as possible. However, it did not consider how that advice should be imparted. The British Columbia Whiplash Initiative (BCWI) ${ }^{6}$ made similar recommendations and presented sample scripts for delivering realistic oral reassurance. Neither QTF nor BCWI offered specific recommendations on written patient information, yet it may be inferred that written material could be used to supplement oral advice.

In a survey of 110 NHS accident and emergency departments in UK (A Auty, unpublished data), 29 provided examples of advice sheets, leaflets, and booklets that they offered to patients with WAD while 12 specifically indicated they did not use any. Eighteen of the 29 were commercially produced advice cards bearing the name and contact number of a local solicitor. The advice was generally not evidence based and did not target the fundamental issues identified by QTF and BCWI. The same was true of internet sources.

Patients want to understand the nature of their injury and its prognosis, as well as how best to manage their pain and reduce disability. Similarly, clinicians need to have and convey confidence in any advice they give. The present evidence review was conducted to provide a scientific framework for patient centred information with the potential to reduce the risk of chronicity in WAD. Specifically, the results were to be used to develop messages for an evidence based patient educational booklet, and to foster consistent oral advice. This focus guided the scope and methodology of the review.

\section{METHODS}

The QTF report published in 1995 provided the first and most widely known, comprehensive literature review and recommendations on WAD. ${ }^{5}$ The BCWI in 1997 developed a teaching package and guidelines for health care professionals, based on the QTF findings. ${ }^{6}$ The reports from the QTF and the BCWI were used as the logical starting points for the present review.

Medline and psycINFO were searched from 1994 through October 2001, using combinations of keywords (whiplash, neck pain, treatment, biomechanics, education) relevant to the whole whiplash phenomenon. This was supplemented by searches on the internet, searches of personal databases, and citation tracking. All aspects of WAD were considered, including clinical and non-clinical studies on QTF Grades 0-III. ${ }^{5}$ QTF

Abbreviations: WAD, whiplash associated disorders; QTF, Quebec Task Force; BCWI, British Columbia Whiplash Initiative 
Grade IV (fracture or dislocation) and surgical interventions were excluded. Initially, abstracts of the retrieved articles were screened by one of the authors for their general content; full papers were obtained for those that appeared applicable. Acceptable studies and reviews were then selected as those that presented information relevant to the management and treatment of whiplash, together with selected articles covering epidemiology, mechanisms of injury, and social policy. Articles not pertinent to the development of patient information, or that did not add to the understanding of injury mechanisms or management in WAD, were excluded. In some areas (notably patient education) the whiplash literature was seriously lacking, so background evidence was taken from selected papers in other musculoskeletal conditions. In addition to the formal search, a few papers published in the last two months of 2001, which were especially relevant to the objectives of the review, were included.

A full systematic review methodology in such a multidisciplinary field would be impracticable and inappropriate, so an alternative strategy had to be adopted. This was based on a qualitative evaluation of the available scientific evidence in each relevant field for its appropriateness for developing patient information. Included articles were scrutinised and the pertinent information extracted; extensive discussion, reiterative drafting, and consensus between the three reviewers resulted in the synthesis of evidence statements reflecting the evidence currently available, while recognising the limitations of that evidence in many areas. Evidence statements were categorised under a number of headings: biomechanics, epidemiology, clinical, investigation, psychology, theoretical models, treatment, education, and social policy (though inevitably there was some overlap between these headings). The strength of the evidence for each statement was then rated qualitatively on its quantity, quality, and consistency by consensus between the three authors:

- Consistent: Generally consistent findings in multiple studies (albeit of variable scientific quality).

- Balance: Balance of available evidence (including existing reviews).

- Limited: Limited or weak scientific evidence.

Thus, the literature review may best be summarised as systematic searching of the published scientific literature with a qualitative evaluation of the quantity, consistency, and relevance of the evidence as the basis for patient information and advice on WAD.

\section{RESULTS}

One hundred and sixty three papers were included in the review and examined in detail. Table 1 lists the evidence statements (with identifying letters) together with a rating of the evidence and links to the references.

The QTF found very little scientifically admissible data. ${ }^{7}$ Having examined all material published since 1994, we feel this is, by and large, still the case. Published studies frequently have methodological shortcomings such as low sample sizes, differing inclusion/exclusion criteria and differing outcome measures, although there were some notable exceptions. In view of the limitations of the scientific evidence we believe, in common with the QTF, that a "best evidence synthesis" is appropriate, and our findings show this can provide a useful overview that highlights areas where there is a reasonable degree of consistency.

\section{Biomechanics}

Biomechanical considerations give some insight into the likelihood of injury, the tissues involved, and the severity of injury. Consistent evidence from both in vitro and in vivo studies suggest that a whiplash type injury can result in tissue injury to various spinal structures; potentially affecting the intervertebral discs, zygapophysial joints, ligaments and muscles (see table 1: B1, B6, B7). The majority of whiplash injuries probably involve predominantly muscles and ligaments, resulting from direct stretching or neuromuscular reflex contractions (B2). Many road traffic accidents involve quite low acceleration perturbations, which are similar to other daily living/sport activities (B5). Consistent findings indicate that relatively low velocity changes can be associated with tissue damage, with the threshold suggested to be $10-15 \mathrm{~km} / \mathrm{h}$ (B3); yet claims may be made for symptoms resulting from accidents with even lower velocity changes (B4). The direction of impact has an influence: for similar vehicle masses, a higher velocity change is required for tissue damage in a front impact or side impact compared with a rear impact, and a poorer prognosis is likely if the neck is rotated or side bent at the time of impact (B9). There is considerable interest in the influence of head restraints on the effects of injury: theoretically head restraints can reduce the incidence and severity of WAD; there is some consensus that the optimum position for a head restraint is close to and level with the head (B8).

\section{Epidemiology}

Data from different countries suggest that recovery rates from WAD differ, probably depending on social and cultural influences. In cultures of low therapeutic involvement and no litigation, symptoms are short lived with little or no link to chronicity (E6). While there has been criticism of the methodology of these studies, the published data are largely consistent. The prevalence of chronic neck pain after a whiplash injury is very similar to the prevalence of chronic neck pain in the general population (E1), making it difficult to determine if persisting symptoms are directly related to the injury or are simply a reflection of the high prevalence of nonspecific neck symptoms in the population at large. From an epidemiological perspective, it is clear that those with continuing symptoms three months after the accident are likely to remain symptomatic for at least two years, possibly much longer (E2). As with other chronic musculoskeletal disorders, people with chronic WAD typically have a high level of multiple complaints (E3). A poorer prognosis has been suggested for certain factors, although the quality of the evidence and the effect size varies: female sex, older age, a high level of symptom severity at onset, pre-traumatic headache, a greater number of symptoms, and pre-existing degenerative changes on radiograph (E4). There is limited evidence on an increased level of symptoms after a second whiplash injury (E5).

\section{Clinical history and examination}

There is conflicting evidence on the value of physical examination in the clinical setting. While a clinical history and physical examination are important to establish the WAD grade (and to identify or exclude more serious injuries), the findings do not pinpoint sources of pain and are not closely related to prognosis $(\mathrm{Cl})$. The most common presenting symptoms are, in descending frequency: neck pain, neck stiffness, headache, low back pain, shoulder pain, and visual disturbance/dizziness (C4), while generalised hyperexcitability and central nervous system sensitisation has been described in a number of studies of patients with chronic WAD (C6). There is persuasive evidence that the clinical outcome at two years can be predicted at three months. It seems that patients who are symptomatic after three months will remain so after two years or more, although their symptoms will fluctuate during this period. The two year outcome can be predicted with an $82 \%$ success rate using a combination of psychological score and neck stiffness assessed at three months (C2). There is consistent evidence that non-collision factors are important in the development of chronic symptoms (including fibromyalgia), emphasising the role of 
psychological and cultural factors (C3), and there is considerable individual variability in terms of response to the accident itself and any resultant symptoms (C5).

\section{Investigations}

According to QTF and BCWI, imaging is unnecessary in Grade 0 -I, but should be performed for Grade II-III to exclude possible fracture or dislocation; though it was accepted that incidental findings unrelated to the injury can be highlighted unnecessarily. More recently, it has been suggested that the extent of radiography could safely be reduced substantially through simple clinical screening, thus limiting unnecessary investigation and consequent costs (In4). The present review suggests that an MRI scan is generally not necessary for Grades 0-II, and probably only helpful for Grade III if surgery is being considered ( $\operatorname{Inl}$ ). MRI scans will reveal a high number of abnormalities, particularly age related changes, in symptom free individuals as well as patients (In2). Conversely, while a high level of abnormalities on MRI has been associated with a poorer prognosis in WAD patients, these abnormalities are most commonly degenerative changes not specifically related to the neck injury $(\operatorname{In} 3)$.

\section{Psychology}

A whiplash injury can certainly trigger emotional and cognitive changes, including travel anxiety, post-traumatic stress disorder, depression, fear of movement, catastrophising, sleep disturbance, and lower levels of concentration (P1, P6). These psychological changes, resulting either from the accident or from the subsequent symptoms and disability, develop secondarily during the first three months after the accident, and do not imply that the pain is psychogenic (P2). When present, psychological factors have a significant detrimental effect on outcomes (including return to work), and recovery tends to parallel psychological improvement (P6, P7). Chronic WAD patients may exhibit inaccurate expectations and amplification of symptoms; they may attribute their entire symptom pattern directly to the road accident, thus contributing to a perpetuation of their problem (P3). Specific coping strategies (active problem solving and perceived confidence in ability to complete daily activities) may be helpful (P5).

\section{Models}

Numerous models have been proposed to explain WAD. It is generally accepted that the biopsychosocial model can explain many clinical and epidemiological findings in WAD (Ml). Accepting an injury event does occur, there is clear evidence for a biological component in the acute presentation (M2). The evidence suggests, however, that the development of chronic symptoms is influenced more by psychological, social, or cultural factors (M3, E6). More controversially, it has been argued that evidence for the construct validity of a causal link between the trauma mechanism and chronic symptoms is sparse, and that whiplash can be conceptualised as being a risk factor for cervical symptoms rather than representing a discrete disease entity (M4).

\section{Treatment}

It has been shown consistently in randomised controlled trials that an early active management strategy is most effective for WAD patients (Grade I to III) (T2). This includes return to pre-accident activities as soon as possible ( $\mathrm{Tl})$, analgesic medication to control symptoms and permit increased activity levels (T4), and prescription of neck specific exercises (T7). Manual therapy (T6), and psychosocial interventions (including cognitive behavioural therapy) may be helpful, particularly for achieving early activation (T5). Collars, rest, and passive physical modalities are generally unhelpful $(\mathrm{T} 3, \mathrm{~T} 8)$. While the use of a soft collar can ease acute symptoms there may be a risk of promoting illness behaviour, especially if used beyond
72 hours (T3). Ill directed and blanket treatment approaches seem likely to contribute to chronic symptoms (T9). Radiofrequency neurotomy can be considered for chronic symptoms (T10), but the relation between those symptoms and the injury may be uncertain (E1). There is limited evidence for the effectiveness of antidepressants in WAD (T11).

\section{Education}

There is general consensus that appropriate information and advice is important (Edl); while there is little information on educational interventions specifically for WAD, there is persuasive evidence from other musculoskeletal literature. It is known that patients want and seek information on health issues (Ed2), and it is important that that information is easy to read, understandable, acceptable, authoritative, believable, and contains practical advice (Ed3). Patients appreciate and retain knowledge from health educational booklets (Ed4); evidenced based patient education (particularly for low back pain) has been shown to have some effect in creating positive shifts in beliefs, improving clinical outcomes, and reducing work loss (Ed4). To counter negative cultural influences on recovery and inconsistent advice given by health care professionals, early delivery of evidenced based information may be optimal for assisting the return to normal activities (Ed4).

\section{Social policy}

The literature showing national and geographical differences in symptom reporting and recovery rates for WAD imply that social factors exert an influence on symptomatology and disability (S1). There is limited evidence to suggest that cultural over-medicalisation may contribute to illness behaviour (S2). Other potential social effects will be outside the control of health care, and involve legal and statutory bodies. Whiplash injuries represent a substantial cost to society, much of which is accounted for by cases lasting over six months (S3); there is therefore a logical basis for early intervention strategies to reduce the significant individual and societal costs.

\section{DISCUSSION}

The important sources of guidance for the management of whiplash (QTF, BCWI) recommend that patients be given reassuring information and advice. The results of this review support that position, and provide a stronger evidence base that active management strategies should have a beneficial influence on outcomes (table 1).

The limitations of this review, its methodology, and the available evidence must be recognised. The literature was searched systematically but, as already emphasised, a proper systematic review methodology was impractical and inappropriate. This was mainly because of the aims and scope of the review, and the range of material included, which was far beyond the randomised controlled trials for which the standard systematic review methodology is designed. Adherence to strict methodological criteria would have excluded much valuable information important to patients and their clinical management. The scope of the review and the criteria for rating the evidence were set to maximise the information available in an area not characterised by high quality studies. In common with QTF, a "best evidence synthesis" seemed the most profitable method for extracting appropriate patient centred messages. In the event, while some areas of the whiplash literature are clearly lacking good scientific evidence, there is a high level of consistency and consensus in many of the areas most pertinent to patient education. There remains, though, a clear need for randomised controlled trials to inform on specific treatment/management protocols, and their optimal timings. 
Table 1 Results of literature review: evidence statements, rating, and linking

\begin{tabular}{|c|c|c|c|c|}
\hline Topic & & Evidence statement & Rating & References \\
\hline \multirow[t]{9}{*}{ Biomechanics } & B1 & Forces involved in road traffic accidents can be sufficient to potentially damage spinal structures; intervertebral discs, zygapophysial joints, muscles, ligaments. & C & 91011121314151617181920 \\
\hline & B2 & Most whiplash injuries involve only the soft tissues. & C & 21222324 \\
\hline & B3 & The threshold for tissue damage is a change in velocity of the order of $10-15 \mathrm{~km} / \mathrm{h}$ (acceleration levels of around $3-4 \mathrm{~g}$ ). & $\mathrm{C}$ & 20252627 \\
\hline & B4 & The threshold for symptom generation is a change in velocity of the order of $4-8 \mathrm{~km} / \mathrm{h}$. & B & 142829 \\
\hline & B5 & Acceleration perturbations of daily living can be greater than those in some vehicle accidents. & L & 30 \\
\hline & B6 & $\begin{array}{l}\text { In some cases, compression may be the most significant force affecting the zygapophysial joints; zygapophysial joints may be important in understanding } \\
\text { chronic symptoms. }\end{array}$ & C & 121519313233 \\
\hline & B7 & Biomechanical analyses should include in vivo studies in order to take account of muscle forces. & B & 34353637 \\
\hline & B8 & Head restraints influence the type and severity of injury. & B & 3839404142434445 \\
\hline & B9 & Head rotated or side-bent at time of injury predicts a poorer prognosis. & C & 46474836 \\
\hline \multirow{6}{*}{ Epidemiology } & El & Chronic symptoms after whiplash have similar prevalence to chronic neck pain in the general population. & C & 4950 \\
\hline & E2 & Symptom status at three months predicts status at 2 years (or more). & C & 515253 \\
\hline & E3 & High prevalence of multiple complaints in those with chronic WAD. & B & 5455 \\
\hline & E4 & $\begin{array}{l}\text { Higher risk of persisting symptoms in some groups: eg, women, older patients, high level of symptoms at onset, high prevalence of pre-traumatic headache, } \\
\text { greater number of symptoms, degenerative changes on rdiography. }\end{array}$ & C & 465657585960616263 \\
\hline & E5 & Reported symptoms may be more severe after a second whiplash injury & L & 64 \\
\hline & E6 & In societies with no litigation and/or low therapeutic involvement WAD is short lived, with little or no link to chronic symptoms. & C & 6566676869 \\
\hline \multirow[t]{6}{*}{ Clinical } & $\mathrm{Cl}$ & Clinical history and examination are important to determine the WAD Grade, but add little to identifying the source of pain or its prognosis. & $\mathrm{C}$ & 11707172 \\
\hline & $\mathrm{C} 2$ & Clinical outcome at 2 years can be predicted at 3 months. & $\mathrm{c}$ & 515253 \\
\hline & $\mathrm{C} 3$ & Non-physical factors are important in the development of chronicity & $\mathrm{c}$ & 57737475767778 \\
\hline & $\mathrm{C} 4$ & $\begin{array}{l}\text { Most common symptoms on presentation: neck pain } \sim 100 \% \text {; neck stiffness } ~ 70 \% \text {; headache } 50-80 \% \text {; low back pain } \sim 60 \% \text {; shoulder pain } 40-75 \% \text {; visual } \\
\text { disturbance/dizziness } 10-50 \% \text {. }\end{array}$ & C & 707980 \\
\hline & C5 & There is considerable individual variability in response to the accident and to symptoms. & B & 1426295581 \\
\hline & C6 & Generalised hyper-excitability, CNS sensitisation, and muscular dysfunction have been hypothesised in chronic whiplash patients. & $\mathrm{C}$ & 22828384 \\
\hline \multirow[t]{4}{*}{ Investigation } & $\ln 1$ & MRI is generally unhelpful except where surgery planned. & B & 8586 \\
\hline & $\ln 2$ & MRI shows high levels of abnormalities in normal, asymptomatic people - particularly age related changes. & C & 878889 \\
\hline & $\ln 3$ & Pre-existing abnormalities on MRI (mainly age related changes), whilst not specifically related to the neck injury, may be a risk factor for longer pain duration. & B & 468790 \\
\hline & $\ln 4$ & Radiographs considered unnecessary for Grades 0-1; advised for Grades II-III; usually negative and can highlight non-relevant findings. & $\mathrm{C}$ & 569192 \\
\hline \multirow[t]{7}{*}{ Psychology } & P1 & Road traffic accident may trigger emotional and/or cognitive changes. & C & 93949596 \\
\hline & P2 & Psychological disturbance may develop in the first three months as a consequence of symptoms. & C & 51819798 \\
\hline & P3 & Expectation, amplification, and attribution are important in development of chronic pain and disability. & B & 99100 \\
\hline & P4 & WAD symptoms can be associated with illness behaviour. & B & 66592 \\
\hline & P5 & Specific coping strategies may be beneficial. & L & 101 \\
\hline & P6 & $\begin{array}{l}\text { Psychological factors, such as anxiety, catastrophising, depression, and fear avoidance, have a significant influence on the clinical picture and on outcomes } \\
\text { (including employment status }\end{array}$ & $\mathrm{C}$ & 102103104105 \\
\hline & P7 & Recovery from WAD symptoms parallels improvement of cognitive disturbances. & c & 106107108 \\
\hline \multirow{4}{*}{ Models } & M1 & Biopsychosocial model applies: similar to other musculoskeletal pain. & C & 10010911011111273 \\
\hline & M2 & An injury event does occur; with potential for some tissue damage, even if the precise structure cannot be identified. & B & 91218113 \\
\hline & M3 & Chronic symptoms developing affer whiplash injury are related closely to the presence of secondary biopsychosocial influences. & B & 7399111114 \\
\hline & M4 & Whiplash may be conceptualised as a risk factor for cervical symptoms rather than a discrete disease entity. & L & 115 \\
\hline \multirow[t]{11}{*}{ Treatment } & $\mathrm{Tl}$ & Faster recovery with return to pre-accident activities as soon as possible. & C & 56116 \\
\hline & T2 & Active treatment is the most effective approach, with the corollary that rest is detrimental. & $\mathrm{c}$ & 611711878119120 \\
\hline & T3 & Collars not helpful (grade I, II, and IIII; certainly beyond 72 hours. & $\mathrm{c}$ & 56121 \\
\hline & T4 & Simple pain control is advantageous for musculoskeletal disorders, including WAD. & B & 56 \\
\hline & T5 & Psychosocial interventions, including cognitive behavioural therapy, are helpful for management of musculoskeletal disorders, including WAD. & $\mathrm{C}$ & 122123124125126 \\
\hline & T6 & Manual therapy (mobilisation and/or manipulation) helpful in the early stages of WAD. & C & 6127128129130131132133 \\
\hline & $\mathrm{T} 7$ & Self exercises helpful for early recovery. & c & 678134 \\
\hline & T8 & Traditional physical therapy modalities have limited effect. & B & 6135 \\
\hline & T9 & Over-medicalisation may contribute to chronic symptoms. & B & 112136137 \\
\hline & $\mathrm{T} 10$ & Radiofrequency neurotomy can reduce symptoms related to zygapophysial joints in chronic WAD. & L & 138139 \\
\hline & $\mathrm{T} 11$ & Antidepressants may relieve pain in chronic WAD & L & 97140 \\
\hline
\end{tabular}




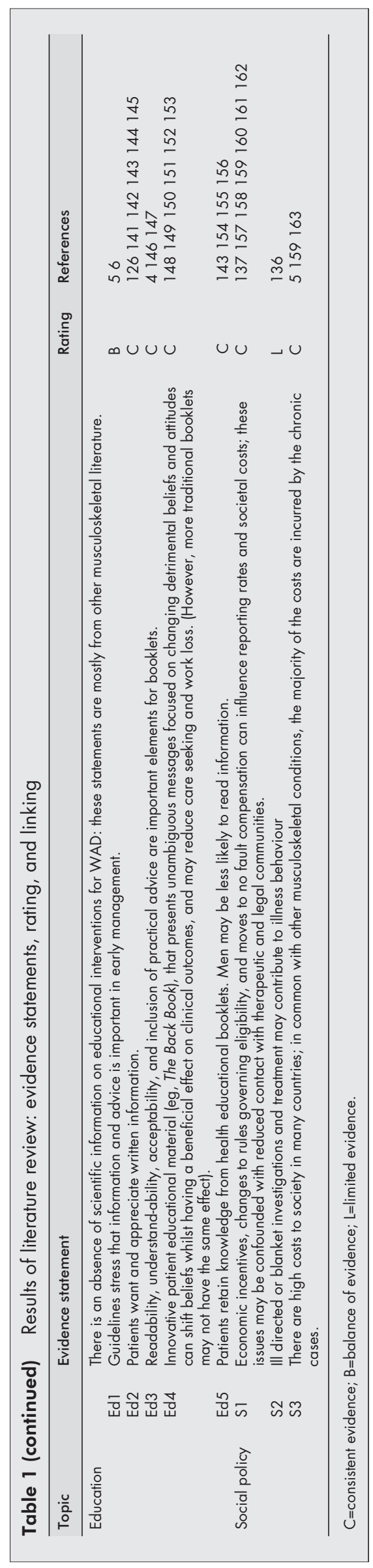

\section{Synthesis of patient centred messages}

The following core set of evidence based messages represents the information and advice that can be given to patients presenting with a WAD. These messages should be conveyed as soon after injury as is reasonably practical. As consistency of information is of fundamental importance, they are presented as a simple list of concepts that all clinicians treating or advising the patient should deliver. Accepting that discussion time with the patient is limited in accident and emergency departments and primary care environments, it is likely to be helpful if the patient can access the same information and advice in written form. To this end, the messages concerned have been incorporated into a booklet that, after peer review and patient evaluation trials, has been published as The Whiplash Book. ${ }^{8}$

After clinical assessment to rule out WAD Grade IV, tackle the following issues, emphasing that they are based on the latest medical research:

- Accept there has been an injury to the neck, but emphasise its benign nature: There has been no serious damage. After a whiplash injury the neck is simply not moving and working properly. The muscles and joints have been affected but they have a natural ability to repair and restore, which is helped by activity.

- Emphasise the favourable prognosis: It should improve rapidly with an active approach; there is no reason why long term disability should ensue. Although symptoms may persist for a while, the acute pain will improve within a few days or weeks, certainly enough to get on with life.

- Recognise other symptoms: Headache, arm pain, jaw pain, and dizziness are common and not a reason for concern.

- Pain control: Use simple analgesia; it's an aid to increasing early activity. Try to find a way to relax and don't worry.

- Prolonged inactivity is unhelpful: Avoiding daily activities slows recovery. Some activities may involve some pain, but hurt is not the same as harm.

- Staying as active as possible is important: Keep moving, don't stay in one position too long, move about before you stiffen up, and don't completely avoid things. Most daily activities and early return to work are helpful.

- Exercises are helpful: Simple neck and shoulder exercises are safe and effective-stretching, strengthening and coordination exercises should be done regularly each day; initial soreness is not a reason for concern.

- Psychological factors (notably distress and fear) are risk factors for chronicity: Don't worry and don't be frightened of movement or pain-activity and a positive approach are the keys to avoiding long term problems. Don't be an avoider.

In summary, the scientific evidence published on WAD since 1994 has increased in scope and quality. In particular, the concept of an early active management approach has been given added strength. Yet the precise mechanism of injury in the majority of patients is still open to speculation and even under active management a proportion of patients will progress to chronicity and remain a clinical challenge. The use of positive reassurance and evidence based advice, given consistently in both oral and written form, is an attractive and inexpensive intervention. Whether it will improve outcomes remains to be tested through randomised clinical trials.

\section{ACKNOWLEDGEMENTS}

This review was funded by The Association of British Insurers.

\section{Contributors}

Tim McClune conducted the search of the scientific lieterature, took part in selecting articles to be considered for analysis and discussion, tabulted relevant papers, contributed to the evidence synthesis, participated in the formulation of evidence statements, and the writing of the paper. Kim Burton took part in the selection of articles, evidence synthesis, formulation of patient centred messages, and writing 
of the paper, and will act as guarantor for the paper. Gordon Waddell monitored the selection of articles, took part in the evidence synthesis, the formulation of patient centred messages, and gave detailed comments on sucessive drafts of the paper. All three authors contributed to the original design and conduct of the research.

\section{Authors' affiliations}

T McClune, A K Burton, G Waddell, Spinal Research Unit, University of Huddersfield, UK

\section{REFERENCES}

1 Coulter A. Evidence based patient information. BM 1998;317:225-6.

2 Simpson M, Buckman R, Stewart M, et al. Doctor-patient communication: the Toronto consensus statement. BM 1991;303:1385-7.

3 Burton AK, Waddell G. Educational and informational approaches. In: Linton SJ, ed. New avenues for the prevention of chronic musculoskeletal pain and disability. Oxford: Elsevier, 2002.

4 Coulter A, Entwistle V, Gilbert D. Informing patients. An assessment of the quality of patient information materials. London: Kings Fund, 1998.

5 Spitzer WO, Skovron ML, Salmi LR, et al. Scientific monograph of the

Quebec Task Force on whiplash-associated disorders: redefining "whiplash" and its management. Spine 1995.20 (suppl):8-73S.

6 Allen M, Barron S, Broudo M, et al. British Columbia Whiplash Initiative-a comprehensive syllabus. Vancouver, BC: Physical Medicine Research Foundation, 1997.

7 Spitzer WO. Scientific approach to the assessment and management of activity-related spinal disorders. A monograph for clinicians. Report of the Quebec Task Force on Spinal Disorders. Spine 1987;12 (suppl): 1-59.

8 Waddell G, Burton AK, McClune T. The whiplash book. Norwich: The Stationery Office, 2001

9 Barnsley L, Lord S, Bogduk N. Whiplash injury. Pain 1994;58:283-307

10 Barnsley L, Lord SM, Wallis BJ, et al. The prevalence of chronic cervical zygapophysial joint pain after whiplash. Spine 1995;20:20-5.

11 Bogduk N. The neck. Baillieres Clin Rheumatol 1999;13:261-85.

12 Bogduk N,. Yoganandan N. Biomechanics of the cervical Spine.III: Minor injuries. Clin Biomech 2001;16:267-75

13 Cusick JF, Pintar FA, Yoganandan N. Whiplash syndrome: kinematic factors influencing pain patterns. Spine 2001;26:1252-8.

14 Davis CG. Injury threshold: whiplash-associated disorders. J Manip Physiol Ther 2000;23:420-7.

15 Grauer JN, Panjabi MM, Cholewicki J, et al. Whiplash produces an S-Shaped curvature of the neck with hyperextension at lower levels. Spine 1997; 22:2489-94

16 Jonsson H, Cesarini K, Sahlstedt B, et al. Findings and outcome in whiplash-type neck distortions. Spine 1994;19:2733-43.

17 Kullgren A, Krafft M, Nygren A, et al. Neck injuries in frontal impacts: influence of crash pulse characteristics on injury risk. Accid Anal Prev 2000;32:197-205

18 Lord SM, Barnsley L, Wallis BJ, et al. Chronic cervical zygapophysial joint pain after whiplash: a placebo-controlled prevalence study. Spine 1996;21:1737-43.

19 Panjabi MM, Cholewicki J, Nibu K, et al. Mechanism of whiplash injury. Clin Biomech 1998;13:239-49.

20 Yoganandan N, Cusick JF, Pintar FA, et al. Whiplash injury determination with conventional spine imaging and cryomicrotomy. Spine 2001;26:2443-8.

21 Brault JR, Siegmund GP, Wheeler JB. Cervical muscle response during whiplash: evidence of a lengthening muscle contraction. Clin Biomech 2000; 15:426-35.

22 Elert J, Kendall SA, Larsson B, et al. Chronic pain and difficulty in relaxing postural muscles in patients with fibromyalgia and chronic whiplash associated disorders. J Rheumatol 2001:28:1361-8.

23 Magnusson ML, Pope MH, Hasselquist L, et al. Cervical electromyographic activity during low-speed rear impact. Eur Spine J 1999;8: $118-25$

24 Nederhand MJ, IJzerman M, Hermens $\mathrm{HJ}$, et al. Cervical muscle dysfunction in the chronic whiplash associated disorder grade (WAD-II). Spine 2000;25: 1938-43

25 Castro WHM, Schilgen M, Meyer S, et al. Do "whiplash injuries" occur in low-speed rear impacts? Eur Spine J 1997;6:366-75.

26 Davis CG. Rear-end impacts: vehicle and occupant response. J Manip Physiol Ther 1998;21:629-39.

27 Krafft M, Kullgren A, Tingvall C, et al. How crash severity in rear impacts influences short-and long -term consequences to the neck. Accid Anal Prev 2000;32:187-95.

28 Brault JR, Wheeler JB, Siegmund GP, et al. Clinical response of human subjects to rear-end automobile collisions. Arch Phys Med Rehabil 1998;79:72-80

29 Ferrari R. The whiplash encyclopedia: the facts and myths of whiplash. Gaithersburg, MA: Aspen Publishers, 1999.

30 Allen ME, Weir-Jones I, Motiuk DR, et al. Acceleration perturbations of daily living: A comparison to whiplash. Spine 1994;19:1285-9.

31 Kaneoka K, Ono K, Inami S, et al. Motion analysis of cervical vertebrae during whiplash loading. Spine 1999;24:763-70

32 Siegmund GP, Myers BS, Davis MB, et al. Mechanical evidence of cervical facet capsule injury during whiplash: a cadaveric study using combined shear, compression, and extension loading. Spine 2001;26:2095-101.
33 Thunberg J, Hellström F, Siölander $\mathrm{P}$, et al. Influences on the fusimotor-muscle spindle system from chemosensitive nerve endings in cervical facet joints in the cat: possible implications for whiplash induced disorders. Pain 2001;91:15-22.

34 Bogduk N. The anatomy and pathophysiology of whiplash. Clin Biomech 1986;1:92-101

35 Gentle CR, Golinski WZ, Heitplatz F. Computational studies of whiplash injuries. Proc Instn Mech Engrs Part H 2001;215:181-9.

36 Jakobsson L, Lundell B, Norin H, et al. WHIPS- Volvo's whiplash protection study. Accid Anal Prev 2000;32:307-19.

37 Yoganandan N, Pintar FA, Kleinberger $M$. Whiplash injury: biomechanical experimentation. Spine 1999;24:83-5.

38 Chapline JF, Ferguson SA, Lillis RP, et al. Neck pain and head restraint position relative to the driver's head in rear-end collisions. Accid Anal Prev 2000;32:287-97.

39 Kleinberger M, Sun E, Saunders J, et al. Effects of head restraint position on neck injury in rear impact. WAD'99 Compendium. Vancouver: Whiplash-Associated Disorders World Congress, 1999 361-90.

40 Maher J. Report investigating the importance of head restraint positioning in reducing neck injury in rear impact. Accid Anal Prev 2000;32:299-305

41 Minton R, Murray P, Stephenson W, et al. Whiplash injury-are current head restraints doing their job. Accid Anal Prev 2000;32:177-85.

42 Siegmund GP, Heinrichs BE, Wheeler JB. The influence of head restraint and occupant factors on peak head/neck kinematics in low-speed rear-end collisions. Accid Anal Prev 1999:31:393-407.

43 Tencer AF, Mirza S, Bensel K. The response of human volunteers to rear-end impacts: the effect of head restraint properties. Spine 2001;26:2432-41.

44 Viano DC, Gargan MF. Headrest position during normal driving implication to neck injury risk in rear crashes. Accid Anal Prev 1996;28:665-74.

45 Welcher JB,.Szabo TJ. Relationships between seat properties and human subjects kinematics in rear impact tests. Accid Anal Prev 2001;33:289-304.

46 Radanov BP, Sturzenegger M, Di Stefano G. Long-term outcome after whiplash injury. A 2-year follow-up considering features of injury mechanism and somatic, radiologic and psychosocial findings. Medicine (Baltimore) 1995;74:281-97.

47 Sturzenegger $M$, Radanov BP, Di Stefano $G$. The effect of accident mechanisms and initial findings on the long-term course of whiplash injury. J Neurol 1995;242:443-9.

48 Winkelstein BA, Nightingale RW, Richardson WJ, et al. The cervical facet capsule and its role in whiplash injury: A biomechanical investigation. Spine 2000;25:1238-46.

49 Bovim G, Schrader H, Sand T. Neck pain in the general population. Spine 1994; 19:1307-9.

50 Squires B, Gargan MF, Bannister GC. Soft-tissue injuries of the cervical spine. J Bone Joint Surg 1996;78-B:955-7.

51 Gargan MF, Bannister GC. The rate of recovery following whiplash injury. Eur Spine J 1994;3:162-4.

52 Maimaris C, Barnes MR, Allen M. Whiplash injuries of the neck: a retrospective study. Injury 1998;19:393-6.

53 Gargan M, Bannister G, Main C, et al. The behavioural response to whiplash injury. J.Bone and Joint Surgery. 1997;79-B:523-6.

54 Cote P, Cassidy JD, Carroll L. The factors associated with neck pain and its related disability in the Saskatchewan population. Spine 2000;25: $1109-17$

55 Berglund A, Alfredsson L, Jensen I, et al. The association between exposure to a rear-end collision and future health complaints. J Clin Epidemiol 2001;54:851-6.

56 Larsen LB, Holm R. Prolonged neck pain following automobile accidents. Gender and age related risk calculated on basis of data from an emergency department. Ugeskr Laeger 2000;162:178-81.

57 Richter M, Otte D, Pohlemann T, et al. Whiplash-type neck distortion in restrained car drivers: frequency, causes and long-term results. Eur Spine J 2000;9:109-17

58 Versteegen GJ, Kingma J, Meijler WJ, et al. Neck sprain after motor vehicle accidents in drivers and passengers. Eur Spine J 2000:9:547-52.

59 Dolinis J. Risk factors for 'whiplash' in drivers: a cohort study of rear-end traffic crashes. Injury 1997;28:173-9.

60 Versteegen GJ, Kingma J, Meijler WJ, et al. Neck sprain not arising from car accidents: a retrospective study covering 25 years. Eur Spine J 1998; 7:201-5.

61 Suissa S, Harder S, Veilleux M. The relation between initial symptoms and signs and the prognosis of whiplash. Eur Spine J 2001;10:44-9.

62 Harder S, Veilleux M, Suissa S. The effect of socio-demographic and crash-related factors on the prognosis of whiplash. J Clin Epidemiol 1998:51:377-84.

63 Hijioka A, Narusawa K, Nakamura T. Risk factors for long-term treatment of whiplash injury in Japan: analysis of 400 cases. Arch Orthop Trauma Surg 2001;121:490-3.

64 Khan S, Bannister G, Gargan M, et al. Prognosis following a second whiplash injury. Injury 1999:31:249-51.

65 Schrader H, Obelieniene D, Bovim G, et al. Natural evolution of late whiplash syndrome outside the medicolegal context. Lancet 1996;347:1207-11.

66 Obelieniene D, Schrader H, Bovim G, et al. Pain after whiplash: a prospective controlled inception cohort study. J Neurol Neurosurg Psychiatry 1999;66:279-83 
67 Partheni M, Miliaras G, Constantoyannis C, et al. Whiplash injury following car accident: rate of recovery. North American Spine Society, 12th Annual Meeting. New York: North American Spine Society, 1997:219.

68 Partheni M, Constantoyannis C, Ferrari R, et al. A prospective cohort study of the outcome of acute whiplash injury in Greece. Clin Exp Rheumatol 2000;18:67-70

69 Virani SN, Ferrari R, Russell AS. Physician resistance to the late whiplash syndrome. J Rheumatol 2001;28:2096-9.

70 Kasch H, Bach FW, Jensen TS. Handicap after acute whiplash injury. Neurology 2001;56:1637-43.

71 Kasch H, Stengaard-Pedersen K, Arendt-Nielsen L, et al. Pain thresholds and tenderness in neck and head following acute whiplash injury: a prospective study. Cephalalgia 2001;21:189-97.

72 Dall'Alba PT, Sterling MM, Treleaven JM, et al. Cervical range of motion discriminates between asymptomatic persons and those with whiplash. Spine 2001;26:2090-4

73 Ferrari R, Schrader $\mathrm{H}$. The late whiplash syndrome: a biopsychosocial approach. J Neurol Neurosurg Psychiatry 2001;70:722-6.

74 White KP, Ostbye T, Harth M, et al. Perspectives on posttraumatic fibromyalgia: a random survey of Canadian general practitioners, orthopaedists, physiatrists and rheumatologists. J Rheumatol 2000;27:790-6

75 Cote $\mathbf{P}$, Hogg-Johnson S, Cassidy JD, et al. The association between neck pain intensity, physical functioning, depressive symptomatology and time-to-claim-closure after whiplash. J Clin Epidemiol 2001;54:275-86.

76 Radanov BP, Sturzenegger M. Predicting recovery from common whiplash. Eur Neurol 1996;36:48-51.

77 Radanov BP, Sturzenegger M, de Stefano G, et al. Relationship between early somatic, radiological, cognitive and psychosocial findings and outcome during a one-year follow-up in 117 patients suffering from common whiplash. BrJ Rheumatol 1994;33:442-8.

78 Soderlund A, Olerund C, Lindberg P. Acute whiplash-associated disorders (WAD): the effects of early mobilization and prognostic factors in long-term symptomatology. Clinical Rehabilitation 2000;14:467.

79 Pearce JM. Headaches in the whiplash syndrome. Spinal Cord 2001;39:228-33.

80 Radanov BP, Di Stefano G, Augustiny KF. Symptomatic approach to posttraumatic headache and its possible implications for treatment. Eur Spine J 2001;10:403-7.

81 Mayou R, Bryant B. Outcome of whiplash neck injury. Injury 1996;27:617-23.

82 Koelbaek Johansen M, Graven-Nielsen T, Schou Olesen A, et al. Generalised muscular hyperalgesia in chronic whiplash syndrome. Pain 1999;83:229-34.

83 Curatolo M, Petersen-Felix S, Arendt-Nielsen L, et al. Central hypersensitivity in chronic pain after whiplash injury. Clin J Pain 2001;17:306-15.

84 Mungali R. Neurobiological mechanisms underlying chronic whiplash associated pain: The peripheral maintenance of central sensitization. Journal of Musculoskeletal Pain 2000;8: 169-78.

85 Pettersson K, Hildingsson C, Toolanen G, et al. Disc pathology after whiplash injury: a prospective magnetic resonance imaging and clinical investigation. Spine 1997:22:283-7.

86 Ronnen HR, de Korte PJ, Brink PR, et al. Acute whiplash injury: is there a role for MR imaging? - a prospective study of 100 patients. Radiology 1996;20:93-6.

87 Bonuccelli, Pavese N, Lucetti C, et al. Late whiplash syndrome: a clinical and magnetic resonance imaging study. Funct Neurol 1999;14:219-25.

88 Boden SD, McCowin PR, Davis DO, et al. Abnormal magnetic-resonance scans of the cervical spine in asymptomatic subjects. A prospective investigation. J Bone Joint Surg Am 1990;72:1178-84.

89 Teresi LM, Lufkin RB, Reicher MA, et al. Asymptomatic degenerative disk disease and spondylosis of the cervical spine: MR imaging. Radiology 1987; 164:83-8.

90 Borchgrevink C, Smevik O, Nordby A, et al. MR imaging and radiography of patients with cervical hyperextension-flexion injuries after car accidents. Acta Radiol 1995;36:425-8.

91 Marx J,.Biros MH. Who is at risk after head or neck trauma? N Engl J Med 2000;343:138-41.

92 Motor Accidents Authority. Guidelines for the management of whiplash-associated disorders. Sydney: Motor Accident Authority, 2001

93 Kessels RP, Aleman A, Verhagen WI, et al. Cognitive functioning after whiplash injury: a meta-analysis. J Int Neuropsychol Soc 2000;6:271-8

94 Radanov BP, Bicik I, Dvorak J, et al. Relation between neuropsychological and neuroimaging findings in patients with late whiplash syndrome. J Neurol Neurosurg Psychiatry 1999;66:485-90.

95 Mayou R. Long-term psychological symptoms. International Whiplash Conference, September 2-4, Bristol: International Whiplash Confrerence, 1997: 167-9

96 Schlesinger I, Hering-Hanit R, Dagan Y. Sleep disturbances after whiplash injury: objective and subjective findings. Headache 2001;41:586-9

97 Mayou R, Bryant B. Outcome in consecutive emergency department attenders following a road traffic accident. Br J Psychiatry 2001; 179:528-34

98 Ratliff AHC. Whiplash injuries. J Bone Joint Surg 1997;79-B:517-19.

99 Ferrari R, Kwan O, Russell AS, Pearce JM, et al. The best approach to the problem of whiplash? One ticket to Lithuania, please. Clin Exp Rheumatol 1999;17:321-6.

100 Ferrari R, Kwan O, Friel J. Illness behaviour and adoption of the sick role in the whiplash claimants. American College of Forensic Examiners, 1999. (www.acfe.com/forensic_article/ferrari/full)
101 Soderlund A, Lindberg P. Long-term functional and psychological problems in whiplash associated disorders. Int J Rehabil Res 1999;22:77-84

102 Heikkila H, Heikkila E, Eisemann M. Predictive factors for the outcome of a multidisciplinary pain rehabilitation programme on sick-leave and life satisfaction in patients with whiplash trauma and other myofascial pain: a follow up study. Clinical Rehabilitation 1998;12:487-96.

103 Klein GN, Mannion AF, Panjabi MM, et al. Trapped in the neutral zone: another symptom of whiplash-associated disorder? Eur Spine J 2001;10:141-8.

104 Vlaeyen JWS, Linton SJ. Fear-avoidance and its consequences in chronic musculoskeletal pain: a state of the art. Pain 2000:85:317-32.

105 Sullivan MJL, Stanish W, Waite H, et al. Catastrophizing, pain, and disability in patients with soft-tissue injuries. Pain 1998;77:253-60.

106 Radanov BP, Begre S, Sturzenegger M, et al. Course of psychological variables in whiplash injury. In: Gunzburg R, Szpalski M, eds. Whiplash injuries: current concepts in prevention, diagnosis and treatment of cervical whiplash syndrome. Philadelphia: Lippincott-Raven 1998:151-9.

107 Radanov BP, Di Stefano G, Schnidrig A, et al. Common whiplash: psychosomatic or somatopsychic? J Neurol Neurosurg Psychiatry 1994; 57:486-90.

108 Radanov BP, Dvorak J. Impaired cognitive functioning after whiplash injury of the cervical spine. Spine 1996;21:392-7.

109 Ferrari R, Russell AS. Point of view. Spine 1999;24:97-8.

110 Kendall NAS, Main C, Linton SJ, et al. Reply to Wallis et al. Pain 1998;78:223-5.

111 Linton SJ. A review of psychological risk factors in back and neck pain. Spine 2000;25: 1 148-56

112 Livingston $M$. Whiplash injury: why are we achieving so little? J R Soc Med 2000;93:526-9.

113 Panjabi MM, Nibu K, Cholewicki J. Whiplash injuries and the potential for mechanical instability. Eur Spine J 1998;7:484-92.

114 Ferrari R, Russell AS. Why blame is a factor in recovery from whiplash injury. Med Hypotheses 2001;56:372-5.

115 Stovner LJ. The nosological status of the whiplash syndrome: a critical review based on a methodological approach. Spine 1996;21:2735-46.

116 Borchgrevink GE, Kaasa A, McDonagh D, et al. Acute treatment of whiplash neck sprain injuries: A randomized trial of treatment during the first 14 days after a car accident. Spine 1998;23:25-31.

117 Peeters GGM, Verhagen AP, de Bie RA, et al. The efficacy of conservative treatment in patients with whiplash injury. Spine 2001;26:E64-73

118 Rosenfeld M, Gunnarsson R, Borenstein P. Early intervention in whiplash-associated disorders: A comparison of two treatment protocols. Spine 2000;25:1782-6.

119 Eck JC, Hodges SD, Humphreys SC. Whiplash: a review of a commonly misunderstood injury. Am J Med 2001;1 10:651-6.

120 Sterner Y, Lofgren M, Nyberg V, et al. Early interdisciplinary rehabilitation programme for whiplash associated disorders. Disabil Rehabil 2001;23:422-9.

121 Gennis $\mathbf{P}$, Miller L, Gallagher EJ, et al. The effect of soft cervical collars on persistent neck pain in patients with whiplash injury. Acad Emerg Med 1996:3:568-73.

122 Soderlund A, Lindberg P. An integrated physiotherapy/ cognitive-behavioural approach to the analysis and treatment of chronic whiplash associated disorders, WAD. Disabil Rehabil $2001 ; 23: 436-47$.

123 Provinciali L, Baroni M, Illuminati L, et al. Multimodal treatment to prevent the late whiplash syndrome. Scand J Rehab Med 1996;28:105-11.

124 Johansson C, Dahl J, Jannert $M$, et al. Effects of a cognitive-behavioural pain management program. Behav Res Ther 1998;36:915-30.

125 Karjalainen K, Malmivaara A, van Tulder M, et al. Multidisciplinary biopsychosocial rehabilitation for neck and shoulder pain among working age adults (Cochrane Review). The Cochrane Library, Issue 3 , Oxford: Update Software, 2000

126 Vendrig AA, Van Akkerveeken PF, McWhorter KR. Results of a multimodal treatment program for patients with chronic symptoms after a whiplash injury of the neck. Spine 2000;25:238-44.

127 Bilkey WJ,.Tomski MA. Manual medicine treatment of the cervical spine and whiplash injury. Physical Medicine and Rehabilitation 2000;14:73-84

128 Hurwitz EL, Aker PD, Adams AH, et al. Manipulation and mobilization of the cervical spine: a systematic review of the literature. Spine 1996;21:1746-58

129 Maigne J. Whiplash and spinal manipulation. In: Gunzburg R, Szpalski $M$, eds. Whiplash injuries: current concepts in prevention, diagnosis and treatment of the cervical whiplash syndrome. Philadelphia: Lippincott-Raven, 1998:193-7.

130 McKinney LA. Early mobilisation and outcome in acute sprains of the neck. BMU 1989:299:1006-8.

131 Mealy K, Brennan H, Fenelon GC. Early mobilization of acute whiplash injuries. BM 1998;292:656-7.

132 Woodward MN, Cook CJ, Gargan M, et al. Chiropractic treatment of chronic whiplash injuries. Injury 1996;27:643-5.

133 Kjellman GV, Skargren E, Oberg B. A critical analysis of randomised clinical trials on neck pain and treatment efficacy. A review of the literature. Scand J Rehabil Med 1999;31:139-52.

134 Goodman R, Frew LJ. Effectiveness of progressive strength resistance training for whiplash: a pilot study. Physiotherapy Canada 2000;52:211-14.

135 Gross AR, Aker PD, Goldsmith $\mathrm{CH}$, et al. Physical medicine modalities for mechanical neck disorders (Cochrane Review). The Cochrane Library - Issue 3. Oxford: Update Software, 2000. 
136 Awerbuch MS. Whiplash in Australia. Med J Aust 2000:157:193-6.

137 Ferrari R. The many facets of whiplash. Spine $2001 ; 26: 2063-4$.

138 Sapir DA, Gorup JM. Radiofrequency medial branch neurotomy in litigant and nonlitigant patients with cervical whiplash: a prospective study. Spine 2001;26:E268-73.

139 Wallis BJ, Lord SM, Bogduk N. Resolution of psychological distress of whiplash patients following treatment by radiofrequency neurotomy: a randomised, double-blind, placebo-controlled trial. Pain 1997:73:15-22.

140 Schreiber S, Vinokur S, Shavelzon V, et al. A randomized trial of fluoxetine versus amitriptyline in musculoskeletal pain. Isr J Psychiatry Relat Sci 2001;38:88-94.

141 Milewa T, Calnan M, Almond S, et al. Patient education literature and help seeking behaviour: perspectives from an evaluation in the UK. Soc Sci Med 2000:51:463-75.

142 Chapman JA, Smith L, Little P, et al. The 'back home' leaflet: developing a self-management leaflet for people with acute low back pain. Journal of Back and Musculoskeletal Rehabilitation 1997;9:61-3.

143 Barlow J, Wright C. Knowledge in patients with rheumatoid arthritis: a longer term follow-up of a randomized controlled study of patient education leaflets. Br J Rheumatol 1998;37:373-6.

144 Kenny DT, Wilson RG, Purves IN, et al. A PIL for every ill? Patien information leaflets(PIL's): a review of past, present and future use. Fam Pract 1998; 15:471-9.

145 Maggs FM, Jubb RW, Kemm JR. Single-blind randomized controlled tria of an educational booklet for patients with chronic arthritis. $\mathrm{Br} J$ Rheumatol 1996;35:775-7.

146 Frost MH, Thompson R, Thiemann KB. Importance of format and design in print patient information. Cancer Pract 1999:7:22-7.

147 Wise PH, Pietroni RG, Bhatt VB, et al. Development and evaluation of a novel patient information system. J Royal Soc Med 1996;89:557-60.

148 Burton AK, Waddell G, Tillotson KM, et al. Information and advice to patients with back pain can have a positive effect: a randomized controlled trial of a novel educational booklet in primary care. Spine 1999;24:2484-91.

149 Nordin M. Back pain: lessons from patient education. Patient Educ Couns 1995;26:67-70
150 Cherkin DC, Deyo RA, Battie M, et al. A comparison of physical therapy, chiropractic manipulation, and provision of an educational booklet for the treatment of patients with low back pain. N Engl J Med 1998;339:1021-9.

151 Cherkin DC, Deyo RA, Street JH, et al. Pitfalls of patient education. Limited success of a program for back pain in primary care. Spine 1996;21:345-55.

152 Roland M. Dixon M. Randomized controlled trial of an educational booklet for patients presenting with back pain in general practice. $J R$ Coll Gen Pract 1989;39:244-6.

153 Symonds TL, Burton AK, Tillotson KM, et al. Absence resulting from low back trouble can be reduced by psychosocial intervention at the work place. Spine 1995;20:2738-45.

154 Berger P, Luskin $M$, Krishel S. Preventive health pamphlets in the emergency department. J Emerg Med 1998;16:691-4.

155 Super A. Improving pain management practice. A medical centre moves beyond educating to document and manage patient care. Health Prog 1996;77:50-4

156 Lennox AS, Osman LM, Reiter E, et al. Cost effectiveness of a computer failored and non-tailored smoking cessation letters in general practice: randomised controlled trial. BM 2001;322:1396-400.

157 Becker N, Hojsted J, Sjogren P, et al. Sociodemographic predictors of treatment outcome in chronic non-malignant pain patients. Do patients receiving or applying for Disability Pension benefit from multidisciplinary pain treatment? Pain 1998;77:279-88

158 Cassidy JD, Carroll L, Cote P, et al. Effect of eliminating compensation for pain and suffering on the outcome of insurance claims for whiplash. N Engl J Med 2000;342:1179-86.

159 Deyo R. Pain and public policy. N Engl J Med 2000;342:1211-13.

160 Swartzman LC, Teasell RW, Shapiro AP, et al. The effect of litigation status on adjustment to whiplash injury. Spine 1996;21:53-8.

161 Rasmussen C, Rechter L, Schmidt I, et al. The association of the involvement of financial compensation with the outcome of cervicobracia pain that is treated conservatively. Rheumatology 2001;40:552-4.

162 Cote P, Cassidy JD, Carroll L, et al. A systematic review of the prognosis of acute whiplash and a new conceptual framework to synthesize the literature. Spine 2001;26:E445-58.

163 Woolf AD, Akesson K. Understanding the burden of musculoskeletal conditions. BM 2001;322:1079-80. 